\title{
AS LICENÇAS DE COPYRIGHT E COPYLEFT NOS SOFTWARES:
}

uma análise sob uma perspectiva jurídico-econômica quanto as modalidades de licença copyright e copyleft consoante o Ordenamento Jurídico Brasileiro

\section{THE COPYRIGHT AND COPYLEFT LICENSES ON SOFTWARES:}

a legal economic analysis about of the copyright and copyleft

modalities of licenses, according to the Brazilian legal order.

\section{LAS LICENCIAS DE COPYRIGHT Y COPYLEFT EM LOS SOFTWARES:}

Una análisis desde uma perspectiva jurídico-económica de las modalidades

de licencias copyright y copyleft, según el Ordenamiento Jurídico Brasileño

\section{Edson Mota Valença Filho ${ }^{1}$}

RECEBIBO 29/05/2019

APROVADO 30/06/2019

PUBLICADO 01/07/2019

Editor Responsável: Carla Caldas

Método de Avaliação: Double Blind Review

E-ISSN: 2316-8080

DOI: 10.16928

\section{RESUMO}

O artigo tem como objeto a análise econômica, sob o prisma da tradição austríaca de economia, do Direito Autoral aplicado aos Programas de Computadores. Nesse sentido, o objetivo geral do trabalho foi a conveniência dos modelos de licença copyright e copyleft sob o prisma da Análise Econômica do Direito.

Palavras-chave: Diretos Autorais. Contratos de Softwares. Copyleft.

\section{ABSTRACT}

The article has as object the economic analysis of software's copyright law under the austrian's economics perspective. In this sense, the general objective of this papper is to analysis the convenience of software's copyright and copyleft licenses under the Law and Economic's perspective.

Key word: Copyright. Software Contract. Copyleft.

\section{RESUMEN}

\footnotetext{
${ }^{1}$ Advogado Empresarial na Mota Valença \& Campos Sociedade de Advogados (R. Quarenta e Oito, n 713 , Empresarial Aurino Duarte, sala 7, Aflitos, Recife/PE, CEP 52050-355), aluno do curso de pós-graduação lato sensu Direito Empresarial e Contratos do Centro Universitário de Brasília (UniCEUB/ICPD), Bacharel em Direito pela Faculdade Damas da Instrução Cristã (FADIC). E-mail: edsonfilho@motavalencacampos.adv.br; Perfil Orcid: https://orcid.org/0000-0002-6595-381X; Currículo Lattes: http://lattes.cnpq.br/2069849159882597; Perfil Google Acadêmico: https://scholar.google.com.br/citations?user=pNSj3z0AAAAJ\&hl=pt-BR
} 
El artículo tiene como objeto el análisis económico, bajo el prisma de la tradición austriaca de economía, del Derecho Autoral aplicado a los Programas de Ordenadores. En ese sentido, el objetivo general del trabajo fue la conveniencia de los modelos de licencias copyright y copyleft bajo el prisma del Análisis Económico del Derecho.

Palabras-claves: Direcho del Autor. Contratos de Software. Copyleft.

\section{INTRODUÇÃO}

A tecnologia da informática marcou o início de uma nova Era, criando, intensificando, atenuando, modificando e "revogando" paradigmas sociais, econômicos e jurídicos. Na sociedade contemporânea é inimaginável viver em total exclusão dos benefícios desses avanços, assim como é desejável viver sem os seus malefícios. Apenas aqueles que vivem em ambientes remotos e "herméticos" estão, talvez, pouco são afetados pelos eventos, produtos e serviços, característicos da Era da Informática.

No mundo contemporâneo distâncias foram "encurtadas" com a criação e utilização em massa da Internet, o conhecimento tornou-se acessível a um baixo custo e novos modelos de empreendimentos passaram a ser possíveis e descobertos. Consequentemente, a ideia da superação do Estado-Nação passou a ser ponderada, defendida e dita até ser inexorável ${ }^{2}$ em um mundo globalizado em sua economia, sociedade e normas jurídicas, questionando necessidade dos Estados-Nações ante os novos tempos e os avanços tecnológicos.

Ante o exposto, é possível identificar algumas contradições a ideia do movimento cryptoanarquista $^{3}$ que impossibilitaram, no passado, e ainda impedem a concretização de uma

\footnotetext{
2 "Governments of Industrial World, you weary giants of flesh and steel, I come from Cyberspace, the new home of Mind. On behalf of the future, I ask you of the past to leave us alone. You are not welcome among us. You have no sovereignty where we gather". BARLOW, John Perry. A declaration of the independence of cyberspace. 1996. Disponível em:https://www.eff.org/cyberspace-independence>. Acesso em: 09 jun. 2018.

${ }^{3}$ Trata-se de um movimento que prega táticas agoristas e ciberativistas com o intuito de implantar um regime anárquico que impere o voluntarismo, economia de livre-mercado e a liberdade. MAY, Timothy $\mathrm{C}$. The Cyphernomicon. 1994. Disponível em: http://www.cypherpunks.to/faq/cyphernomicron/cyphernomicon.html> Acesso em: 01 set. 2018.
} 


\section{AS LICENÇAS DE COPYRIGHT E COPYLEFT NOS SOFTWARES \\ E-ISSN 2316-8080}

verdadeira anarquia no cyberspace ${ }^{4}$, são elas exempli gratia: a proteção à propriedade intelectual desejada pelos criadores de softwares $^{5}$ e hardwares $^{6}$.

O instituto legal da Propriedade Intelectual, apesar da existência de um organismo internacional e inúmeros trados e acordos que versem sobre o assunto, é um mecanismo de proteção contra a concorrência desleal à nível local, regional e internacional, fortemente ligado a figura do Estado-Nação. Nesse sentido, é natural que os desenvolvedores, mentes inventivas, empresários e companhias do segmento da informática incluam em seus empreendimentos os benefícios disponíveis nesse sistema.

Ademais, a pertinência da proteção jurídica das tecnologias supramencionadas deve ser avaliada casuisticamente de acordo com o modelo de negócio desejado e compatível com o produto/serviço. Os empreendimentos envolvendo o software, objeto desse trabalho, podem optar pela proteção do copyright, copyleft ${ }^{7}$ ou segredo comercial - proteção dada a um elemento do programa de computador que não é protegido pelos direitos autorais e nem pela propriedade industrial -, restando a dúvida: quais vantagens dessas modalidades.

A prima facie, a licença do copyright permite o sucesso financeiro ao proprietário em razão da exclusividade da exploração do código-fonte durante o prazo legal estipulado, permitindo inicialmente o monopólio, o cenário mais desejável para o titular do direito, sobre a funcionalidade daquele produto/serviço e após a expiração do período a concentração do mercado em decorrência da notoriedade. Já a modalidade copyleft permite a divulgação do código-fonte, sobre certas circunstâncias, com os fins do desenvolvimento difuso dele, permitindo que as imperfeições sejam corrigidas e os programas de computador ganhem notoriedade pela ocupação no mercado.

Isto exposto, o objetivo geral desse artigo é analisar a conveniência das modalidades de copyright e copyleft nas licenças de software, sendo adotada a metodologia hipotético dedutiva e o âmbito da pesquisa bibliográfica.

\footnotetext{
${ }^{4}$ A sensação de "encurtar" as distâncias causadas pela rede mundiais de computadores cria a sensação da existência de um lugar denominado cyberspace presente em todos os territórios e ao mesmo tempo em nenhum. LÉVY, Pierre. O ciberespaço como um passo metaevolutivo. Revista FAMECOS, Porto Alegre, v. 7, no 13, p. 59-67, dez., 2000; MUSSO, Pierre. Critque des réseaux. Paris: Presses Universitaires de France, 2003, p. 332-334.

${ }^{5}$ Software ou programa de computador é a parte lógica, é o código que instruí o hardware a desempenhar uma função determinada. Nesse sentido, o artigo $1^{\circ}$ da Lei $n^{\circ}$ 9.609/1998 define como: "programa de computador é a expressão de um conjunto organizado de instruções em linguagem natural ou codificada, contida em suporte físico de qualquer natureza, de emprego necessário em máquina automáticas de tratamento de informações, dispositivos, instrumentos ou equipamentos periféricos, baseados em técnica digital ou análoga, para fazê-los funcionar de modo e para fins determinados".

${ }^{6}$ Hardware é o conjunto de componentes eletrônicos, circuitos de fios e luz, equipamentos et cetera, que compõe a parte física necessária para o funcionamento do dispositivo eletrônico.

${ }^{7} \mathrm{O}$ termo é derivado da expressão "Copyleft: all rights reversed" a qual é um trocadilho com a frase inglesa "Copyright: all rights reserved", expressando, com certa ironia, o ideário oposto aos direitos autorais.
} 
Nesse diapasão, são objetivos específicos dessa obra: a) estudar a natureza jurídica da Propriedade Intelectual dos softwares, presente na Lei $n^{\circ}$ 9.609/1998 e subsidiariamente na Lei $n^{\circ}$ 9.610/1998; em seguida, b) analisar o licenciamento, os seus requisitos e a modalidade copyleft; por fim, c) avaliar as vantagens das modalidades de licenciamento copyright e copyleft sob a perspectiva econômica da Escola Austríaca de economia.

\section{A PROPRIEDADE INTELECTUAL E OS SOFTWARES}

A Propriedade Intelectual é o instituto jurídico que delega uma série de proteções a exploração comercial dos bens imateriais e o exercício criativo, inovador e inventivo, com o fim de evitar uma concorrência desleal e incentivar o avanço tecnológico, cultural e econômico. Em outras palavras, tais leis buscam "subsidiar" legalmente atividade de artistas, autores e inventores, além de estabelecer condutas de mercado sustentáveis com o fim de criar um ponto de equilíbrio que favoreça o progresso.

Sob esses fundamentos, tais direitos foram esculpidos nas normas constitucionais da Constituição Federal de 1988 (CF/88) em seu artigo 5º, incisos XXVII ${ }^{8}$ e XXIX ${ }^{9}$, que integram os Direitos Autorais, o copyright, e o Direito Industrial, espécies do gênero Propriedade Intelectual. Ademais, tal instituto é constituído como um dos direitos e garantias individuais ${ }^{10}$ e gozam do status jurídico de cláusula pétrea ${ }^{11}$ na $\mathrm{CF} / 88$, consoante o artigo $60, \S 4^{\circ}$, da Magna Carta $^{12}$. Consequentemente, as leis, emendas, normas, atos normativos, et cetera, que proponham em seu teor, expressamente ou implicitamente, a abolição da Propriedade Intelectual afrontará normas constitucionais consequentemente sendo inconstitucionais.

O Direito à Propriedade Intelectual no Brasil protege a atividade criativa nas seguintes modalidades: direitos autorais e conexos, as patentes, modelos de utilidades, desenhos

\footnotetext{
${ }^{8}$ O artigo 27, (2), da Declaração Universal dos Direitos do Humanos de 1948 dispõe como direito universal inerente ao homem os direitos de morais e de exploração comercial sobre obras cientificas literais ou artísticas.

9 “a lei assegurará aos autores de inventos industriais privilégio temporário para sua utilização, bem como proteção às criações industriais, à propriedade das marcas, aos nomes de empresas e a outros signos distintivos, tendo em vista o interesse social e o desenvolvimento tecnológico e econômico do País" (grifos acrescidos).

${ }^{10}$ São direitos fundamentais e inerentes aos seres humanos, consagrados em tratados internacionais e constituições estrangeiras, constituindo marco legal que põe um "divisor de água" na história e propõem uma nova Era de Civilidade, onde deve ser perseverado a concretização desses direitos e garantias em função da dignidade da pessoa humana, ver mais: SARLET, Ingo Wolfgang. Dignidade (da pessoa) humana e direitos fundamentais na Constituição Federal de 1988. 10. ed. rev. atual. e ampl. - Porto Alegre: Livraria do Advogado Editora, 2015.

${ }^{11}$ SARLET, Ingo Wolfgang. Os direitos fundamentais sociais como "cláusulas pétreas". Caderno de Direito, Piracicaba, v. 3, n. 5, p.78-97, jul./dez. 2003.

12 "Não será objeto de deliberação a proposta de emenda tendente a abolir: a forma federativa de Estado; o voto direto, secreto, universal e periódico; a separação dos Poderes; os direitos e garantias individuais" (grifos acrescidos).
} 


\section{AS LICENÇAS DE COPYRIGHT E COPYLEFT NOS SOFTWARES \\ E-ISSN 2316-8080}

industriais, indicação geográfica, marca, segredo industrial e concorrência desleal. Além disso, há a proteção sui generis ao programa de computador, topografia de circuitos integrados e as tecnologias de cultivares ${ }^{13}$ as quais enquadram-se no regime jurídico dos direitos autorais, no caso software, e patentes, relativo aos outros citados, com peculiaridades.

Ademais, apesar de ser essencialmente ligado ao Estado-Nação, e aos limites fronteiriços, os direitos a Propriedade Intelectual gozam de reconhecimento internacional, possuindo convenções, tratados, acordos bilaterais e multilaterais, organismos e mecanismos de solução de conflitos ${ }^{14}$ supranacionais, os quais tem como função a uniformidade da proteção dos avanços tecnológicos e a globalização das economias criativa e inventiva nacionais ${ }^{15}$.

Por sua vez, o Brasil é signatário da Convenção de Paris, ratificada pelo Decreto $\mathrm{n}^{\mathrm{o}}$ 75.572/1975, ingressando a Organização Mundial da Propriedade Intelectual (OMPI), além de signatário do Acordo TRIP, inserido em nosso ordenamento jurídico pelo Decreto $\mathrm{n}^{\mathrm{o}}$ $1.355 / 1994$.

\subsection{Histórico da propriedade intelectual}

O interesse pela tutela jurídica sobre as ideias, seus empregos nas atividades comerciais e a necessidade da intervenção estatal com o fim de proporcionar um ambiente concorrencial sustentável ao criador tornou-se mais presente com o advento da Primeira Revolução Industrial. Em períodos anteriores aquela Era, a dificuldade no emprego da engenharia reversa dispensava aos inventores a necessidade da assistência das autoridades estatais, sendo o principal método de proteção às invenções: os segredos industriais.

\footnotetext{
${ }^{13}$ Em virtude da complexidade da natureza tecnológica o legislador brasileiro optou por detalhar em lei especifica o regime jurídico distinto, sendo a Lei $n^{\circ}$ 9.609/1998 aplicada aos programas de computador, a Lei $\mathrm{n}^{\circ}$ 11.484/2007 resguardando a topografia de circuitos integrados e a Lei $n^{\circ}$ 9.456/1998 vigente para as tecnologias de cultivares. ${ }^{14} \mathrm{O}$ artigo 64 do Acordo sobre Aspectos do Direito de Propriedade Intlectual Relacionado ao Comércio (ADPIC) ou Agreement on Trade-Related Aspects of Intellectual Property Rights (TRIP) elege o sistema de solução de controvérsias da Organização Mundial de Comércio (OMC), para versar sobre as disputas em relação a Propriedade Intelectual, substituindo o recurso facultativo a Corte Internacional de Justiça prevista na Convenção de Paris, versão de Estocolmo, 1967, artigo 28. PIMENTEL, Luiz Otávio. O acordo sobre os aspectos dos direitos de propriedade intelectual relacionados com o comércio. Seqüência: Estudos Jurídicos e Políticos, Florianópolis, p. 167-196, jan. 2002, p.190. ISSN 2177-7055. Disponível em: https://periodicos.ufsc.br/index.php/sequencia/article/view/15338>. Acesso em: 08 set. 2018.

${ }^{15}$ Consoante os artigos $3^{\circ}$ e $4^{\circ}$ da Convenção de Estocolmo 1967, ver mais em: PIMENTEL, Luiz Otávio. O acordo sobre os aspectos dos direitos de propriedade intelectual relacionados com o comércio. Seqüência: Estudos Jurídicos e Políticos, Florianópolis, p. 167-196, jan. 2002, p.169. ISSN 2177-7055. Disponível em: https://periodicos.ufsc.br/index.php/sequencia/article/view/15338>. Acesso em: 08 set. 2018.
} 
Nesse referido período da história começou o desenvolvimento do sistema de propriedade intelectual moderno. Todavia, remontam a Era da Renascença casos de privilégios concedidos pelos municípios como exceções as leis. Nesse momento, não pesava o argumento sobre o reconhecimento ao direito do autor, sendo tais direitos dados na forma de: exploração comercial exclusiva de inventos ou a de publicação de obras pelos autores ou publicadores ${ }^{16}$.

O registro mais antigos de "patente" concedida foi o monopólio de 5 anos dados a Johannes de Speyer na República de Veneza para impressão de livros em 1469, não reconhecendo diferença entre o direito de autores e de inventores ${ }^{17}$. Nesse modelo de privilégios, sobressaltava-se o direito dos donos de impressas sobre os dos autores, sendo ele empregado, mais tarde, pelos Estados Monárquicos do Século XVI ${ }^{18}$.

As "patentes" sobre a impressão eram dadas pelos monarcas daquelas épocas comumente como formas de censura e controle no comércio de livros, quanto aos inventos eram concedidas como formas de subsídios para a promoção dos avanços tecnológicos dentro das fronteiras do reino. Na Inglaterra, durante 1476 até 1710 a Company of Stationers of London operou em monopólio no território inglês até a promulgação do Estatuto da Rainha Ana, que reconheceu o direito de publicação aos autores e não mais aos poucos licenciados pela Coroa Inglesa ${ }^{19}$.

No Brasil, o sistema de patentes foi reformulado pelo Alvará de D. João XVI em 1806 como plano de desenvolvimento do Brasil, tal sistema buscava atrair inventores estrangeiros para a nação brasileira, incentivar novas indústria no país e a atividade inventiva, consequentemente um avanço tecnológico. O sistema previa concessão de subsídios aos estrangeiros que desejassem comercializar inventos patenteados em outros países e estabelecia prazos da patente de acordo com a qualidade do invento ${ }^{20}$.

Ademais, o caráter notório da propriedade intelectual durante a chegada da corte portuguesa até o Brasil Imperial era o desejo de promover a inovação e industrialização do país,

\footnotetext{
${ }^{16}$ KOSTYLO, Joanna. From gunpowder to print: the common origins of copyright and patent. In: DEAZLEY, Ronan; KRETSCHMER, Martin; BENTLY, Lionel. Privilege and Property: Essays on the history of copyright.Cambridge OpenBook Publishers: 2010, p. 22.

${ }^{17}$ KOSTYLO, Joanna. From gunpowder to print: the common origins of copyright and patent. In: DEAZLEY, Ronan; KRETSCHMER, Martin; BENTLY, Lionel. Privilege and Property: Essays on the history of copyright.Cambridge OpenBook Publishers: 2010, p.23-25.

18 ZANINI. Leonardo Estevam de Assis. O Estatuto da Rainha Ana: estudos em comemoração dos 300 anos da primeira lei de copyright. Revista do Tribunal Regional Federal da $1^{\text {a }}$ Região, Brasília, v. 22, n. 9, ou. 2010.

19 ZANINI. Leonardo Estevam de Assis. O Estatuto da Rainha Ana: estudos em comemoração dos 300 anos da primeira lei de copyright. Revista do Tribunal Regional Federal da $1^{\text {a }}$ Região, Brasília, v. 22, n. 9, ou. 2010.

${ }^{20}$ CABELLO, Andrea Felippe; PÓBOA, Luciano Martins Costa. Análise econômica da primeira Lei de Patenttes brasileiras. Estud. Econ., São Paulo, v. 46, n. 4, p. 870-907, dec. 2016.
} 


\section{AS LICENÇAS DE COPYRIGHT E COPYLEFT NOS SOFTWARES \\ E-ISSN 2316-8080}

sendo a concessão da patente, a exploração com exclusividade, uma compensação ao inventor por revelar o segredo industrial do objeto patenteável ao Estado Brasileiro.

Quanto aos direitos autorais a primeira legislação brasileira a tratar sobre essa questão foi o artigo 261 do Código Criminal do Império do Brazil que proibia, enquanto o autor ou tradutor estivesse vivo e caso tivesse herdeiro, 10 (dez) anos após sua morte, a cópia e alteração sem autorização da obra literárias ou artísticas feitas ou traduzidas por brasileiro. A penalidade ao crime era o confisco dos exemplares ou a prestação do valor, caso não fosse possível, e multa sob 3 (três) vezes o valor do exemplar. Ademais, a lei também garantia o direito autoral às corporações no período de $10(\mathrm{dez})$ anos $^{21}$.

A Constituição de 1891 foi a primeira Magna Carta Brasileira a tutelar os Direitos do Autor e somente após um intervalo de 68 (sessenta e oito) anos entre a primeira legislação a versa sobre os direitos do autor é que foi promulgada a Lei $n^{\circ} 498 / 1898$, a primeira lei especifica sobre Direitos Autorais no Brasil.

\subsection{Características da propriedade intelectual: privilégios ou propriedade}

Ante o exposto quanto a história do instituto legal da Propriedade Intelectual, resta esclarecer suas características e apontar a polêmica quanto ao seu regime. Antemão, foi descrito que tal instituto destinado a proteger o bem incorpóreo que é o fruto da criatividade específico para uma funcionalidade, no caso das patentes, e de uma obra literária artística ou científica, no caso dos direitos autorais.

Durante a história, a proteção jurídica a essas propriedades era confundida com a um privilégio, como foi exposto, o qual era dado o monopólio sobre uma tecnologia ou uma atividade comercial, no caso da venda de livros, a alguém por um período determinado. As justificativas aqueles sistemas de privilégios poderiam ir desde o desenvolvimento tecnológico $^{22}$ ao controle de informações e do comércio pelo Estado licenciador ${ }^{23}$.

\footnotetext{
21 "Art. 261. Imprimir, gravar, lithographar, ou introduzir quaesquer escriptos, ou estampas, que tiverem sido feitos, compostos, ou traduzidos por cidadãos brasileiros, emquanto estes viverem, e dez annos depois da sua morte, se deixarem herdeiros.

Penas - de perda de todos os exemplares para o autor, ou traductor, ou seus herdeiros; ou na falta delles, do seu valor, e outro tanto, e de multa igual ao tresdobro do valor dos exemplares.

Se os escriptos, ou estampas pertencerem a Corporações, a prohibição de imprimir, gravar, lithographar, ou introduzir, durará sómente por espaço de dez anos".

${ }^{22}$ KOSTYLO, Joanna. From gunpowder to print: the common origins of copyright and patent. In: DEAZLEY, Ronan; KRETSCHMER, Martin; BENTLY, Lionel. Privilege and Property: Essays on the history of copyright.Cambridge OpenBook Publishers: 2010, p.23-25.

${ }^{23}$ ZANINI. Leonardo Estevam de Assis. O Estatuto da Rainha Ana: estudos em comemoração dos 300 anos da primeira lei de copyright. Revista do Tribunal Regional Federal da $\mathbf{1}^{\mathbf{a}}$ Região, Brasília, v. 22, n. 9, ou. 2010.
} 
Atualmente, as justificativas que endossam a Propriedade Intelectual vão desde motivos utilitários, argumentos econômicos, até deontológicos, éticos e morais ${ }^{24}$, vis-à-vis, contra a esse instituto há, também, argumentos utilitários e deontológicos. Tais argumentos serão explanados em tópico mais oportuno nessa obra.

Tradicionalmente, o Direito à Propriedade tem como caráter essencial o exercício monopolístico legítimo e justo sob um bem específico e escasso ${ }^{25}$. Sob essa fundamentação, é irrelevante a materialidade do bem desde que essa não culmine na ausência da escassez do objeto, sob prejuízo da irrelevância da aplicação desse instituto jurídico ou perpetuação de controvérsias $^{26}$.

O regime jurídico da propriedade intelectual concede natureza de escassez ${ }^{27}$ a algo abstrato permitindo o controle contra a reprodução não-autorizada dessa abstração, id est, de forma genérica, é o controle parcial sob o exercício da propriedade alheia que foi empregada na concretização de uma abstração ${ }^{28}$. Nesse sentido, tal instituto relativiza a propriedade tradicional impondo novos limites aos poderes delegados por lei. Logo, é uma forma sui generis de propriedade em razão da escassez legal que a constitui.

\footnotetext{
${ }^{24}$ DEAZLEY, Ronan; KRETSCHMER, Martin; BENTLY, Lionel. Privilege and Property: Essays on the history of copyright.Cambridge OpenBook Publishers: 2010, p.4.

25 "To develop the concept of property, it is necessary for goods to be scarce, so that conflicts over the use of these goods can possibly arise. It is the function of property rights to avoid such possible clashes over the use of scarce resources by assigning rights of exclusive ownership. Property is thus a normative concept: a concept designed to make a conflict-free interaction possible by stipulating mutually binding rules of conduct (norms) regarding scarce resources". HOPPE, Hans-Hermann. A theory of socialism and capitalism. Boston: Kluwer Academic Publishers, 1989, p. 18.

26 "[O]nly because scarcity exists is there even a problem of formulating moral laws; insofar as goods are superabundant ("free" goods), no conflict over the use of goods is possible and no action-coordination is needed. Hence, it follows that any ethic, correctly conceived, must be formulated as a theory of property, i.e., a theory of the assignment of rights of exclusive control over scarce means. Because only then does it become possible to avoid otherwise inescapable and unresolvable conflict". HOPPE, Hans-Hermann. A theory of socialism and capitalism. Boston: Kluwer Academic Publishers, 1989, p. 235.

27 "It is a peculiarity of Property rights in patentes (and copyrights) that they do not arise out of the scarcity of the objects which become approprieated. They are not a consequence of scarcity. They are the deliberate creation of statute law, and, whereas in general the institution of private property makes for the preservation of scarce goods, tending... to led us "to make the most of them,", property rights in patents and copyrights make possible the creation of a scarcity of the products appropriated which could not otherwise be maintained". PLANT, Arnold. The economic theory concerning patents for inventions. In: PLANT, Arnold. Selected economic essays and addresses. London: Routledge \& Kegan Paul, 1974, p.36.

28 “(...) IP rights gibe to pattern-creators partial rights of control - ownership - over the tangible property of everyone else. The pattern-creator has partial ownership of others's property, by virtue of his IP right, because he can prohibit them from performing certain actions with their own property. Author X, for example, can prohibit a third party, Y, from inscribing a certain pattern of words on Y's own blank pages with Y's own ink.(..) IP rights change the status quo by redistributing property from individuals of one class (tangible-property owners) to individuals of another (authors and inventors). Prima facie, therefore, IP law trespasses against or "takes" the property of property owners, by transferring partial ownership to authors and inventors. It is this invasion and redistribution of property that must be justified in order for IP rights to be valid.”, KINSELLA, Stephan Kinsella. Against Intellectual Property. Journal of Libertarian Studies, v. 15, n. 2, pp. 1-55, 2001, p.25.
} 
Ademais, o objeto a ser protegido pelo instituto das patentes e direitos autorais enfrentam também a necessidade de individualização. A legislação brasileira e internacional propõe em seus artigos a limitação da concessão da proteção aquelas ideias que reproduzem um padrão individualizado e formulam uma expressão registrada ou registrável em um suporte físico, no caso do copyright, e com funcionalidade de uma técnica prática e possível de reproduzir no mundo concreto, no caso da propriedade industrial - patente e modelo de utilidade.

Isto exposto, qualificar a propriedade intelectual como um privilégio legal é plenamente aceitável. Todavia, prospera o argumento que abone a propriedade intelectual como o resultado da proteção frente ao abuso do Direito à Propriedade Intelectual feita por terceiros, sendo essa uma justificativa que caracteriza a propriedade intelectual como um regime protetivo em face a concorrência desleal.

\subsection{O regime de proteção jurídica dos programas de computador}

A Revolução Industrial do Século XVIII foi o grande marco histórico para a relevância da propriedade intelectual, a crescente econômica na Inglaterra e os avanços na tecnologia do motor a vapor impulsionaram e industrializaram o país anglo-saxão. Tal fenômeno, repercutiu na urbanização da civilização ocidental e no aumento da capacidade empresarial e no número de empreendimentos.

Atualmente, a tecnologia da informática é dita como responsável pela Terceira Revolução Industrial, sendo característico da contemporaneidade a vasta produção de bens, de empreendimentos e a globalização. Ademais, a conexão de redes de computadores em escala mundial permitiu o fenômeno do e-commerce e uma maior acessibilidade para o cidadão comum empreender a um baixo custo.

Sob esses termos, os programas de computadores são os produtos/serviços ideais na atividade empresarial do comércio eletrônico em virtude da sua capacidade de tradição instantâneas e a baixo custo, potencial de alcance que transcende as distâncias - o cyberspace -, variedade de funcionalidades para os consumidores e, até mesmo, para outros empreendimentos. Consequentemente, há a ampla concorrência nesse mercado globalizado, a pirataria, práticas de engenharia reversa, a dificuldade e onerosidade exacerbada em aplicar as leis em razão da extraterritorialidade do espaço cibernético. A mencionada problemática está 
conexa a já pormenorizada relação da Propriedade Intelectual e o Estado-Nação, além do regime jurídico de proteção desse instituto e a natureza do seu objeto.

Ademais, as demandas de proteção dos empreendedores da informática aos softwares fomentaram o debate quanto a qual modalidade de proteção, direitos autorais ou industrial, deveria ser aplicada e qual o prazo adequado ao contexto do mercado eletrônico ${ }^{29}$. Tendo em vista a limitação dos Estados-Nações, das normas internacionais, além do caráter acelerado das inovações das técnicas na Era da Informática o regime da propriedade intelectual poderia desequilibrar o mercado perpetuando cenários de concorrência desleal e de desproteção aos frutos da criatividade ${ }^{30}$.

Nesse sentido, em consonância com o artigo 2, (1), da Convenção de Berne, a OMPI entendeu, após sediar um debate com especialistas, que a natureza dos programas de computadores enquadrava-se como expressões de linguagem lógica que instruíam os computadores, hardware, para o desempenho de uma funcionalidade, logo sendo obras literárias e sujeitas ao regime dos direitos autorais ${ }^{31}$.

Entretanto, em razão da amplitude da interpretação do artigo 27, (1), do TRIP ${ }^{32}$ para concessão de patentes alguns países permitiram a atribuição do instituto da propriedade industrial para os softwares que apresentassem um caráter técnico (technical character) ou uma função técnica (technical teaching) ${ }^{33}$. Sob esse entendimento, a Suprema Corte dos Estados Unidos da América concedeu em 1981 patente a funcionalidade de um software usado para o processamento de borracha e, em 1990, consagrou o entendimento de que era patenteável o programa de computador cuja função criasse mudanças no mundo fenomenológico ${ }^{34}$.

No Brasil, a Lei $n^{\circ}$ 9.609/1998, a Lei do Software, adotou o sistema de copyright como o sistema de proteção jurídica dos programas de computadores, sendo a Lei $n^{\circ}$ 9.610/1998 aplicada de forma subsidiaria. Todavia, é possível sustentar a tese, sob a lógica do artigo 10,

${ }^{29}$ World Intelectual Property Organization. Intellectual Property Handbook: Police, Law and Use. 2. ed. Geneva: WIPO Publication, 2004, p. 436.

30 Andrade, Elvira et al.Propriedade Intelectual em Software: o que podemos apreender da experiência internacional? Revista Brasileira de Inovação, Rio de Janeiro, v. 6, n. 1, p. 31-53, janeiro/junho 2007, p. 33.

31 World Intelectual Property Organization. Intellectual Property Handbook: Police, Law and Use. 2. ed. Geneva: WIPO Publication, 2004, p. 436.

32 "Subject to the provisions of paragraphs 2 and 3, patents shall be available for any inventions, whether products or processes, in all fields of technology, provided that they are new, involve an inventive step and are capable of industrial application. (5) Subject to paragraph 4 of Article 65, paragraph 8 of Article 70 and paragraph 3 of this Article, patents shall be available and patent rights enjoyable without discrimination as to the place of invention, the field of technology and whether products are imported or locally produced" (grifos acrescidos).

${ }^{33}$ PIMENTEL, Luiz Otávio; SILVA, Cláudio Eduardo Regis de Figueiredo e. Conceito jurídico de software, padrão proprietário e livre: políticas públicas. Sequência (Florianópolis), Florianópolis, n. 68, p. 291-329, jun. 2014, p.300.

34 Andrade, Elvira et al. Propriedade Intelectual em Software: o que podemos apreender da experiência internacional? Revista Brasileira de Inovação, Rio de Janeiro, v. 6, n. 1, p. 31-53, janeiro/junho 2007, p.40-41. 


\section{AS LICENÇAS DE COPYRIGHT E COPYLEFT NOS SOFTWARES \\ E-ISSN 2316-8080}

inciso V, da Lei $\mathrm{n}^{\mathrm{o}}$ 9.279/1998 35 culminado com supramencionado artigo 28, (1), do TRIPs, da concessão de patentes e modelos de utilidade para os softwares que possuam em sua funcionalidade caráter técnico capaz de provocar mudanças no mundo concreto e satisfação dos demais outros requisitos da Lei de Propriedade Industrial.

O copyright aplicado aos programas de computadores no Brasil estabelece que a proteção jurídica dos programas de computadores começa a partir da sua criação pelo prazo de 50 (cinquenta) anos contados a parti de $1^{\circ}$ de janeiro do ano subsequente da publicação ou, caso não tenha sido publicado, da criação, conforme o artigo 2, §2 , da Lei do Software. Em outras palavras, é facultado, consoante o artigo $3^{\circ}$ da supramencionada lei, o registro no órgão responsável pela ciência e tecnologia competente.

Ademais, tal proteção dá ao titular do direito ${ }^{36}$ prerrogativas quanto ao: direitos morais e patrimoniais sobre a obra, garantido o poder de reivindicar a paternidade do software e de impedir que este seja modificado, sem sua autorização, de forma que viole a honra e reputação do criador. Já quanto aos direitos patrimoniais, é concedido a exploração econômica com exclusividade sobre o código-fonte ${ }^{37}$ e sendo garantido ao titular o direito de licenciar ou ceder tais direitos a terceiros.

\subsection{O movimento copyleft: uma opção alternativa para exploração econômica dos softwares}

$\mathrm{Na}$ contramão de alguns empresários da área da informática e programadores, um movimento a favor da flexibilização da propriedade intelectual, da circulação de informações e desenvolvimento tecnológico, passou a defender a iniciativa dos softwares livres em nome da liberdade. Tais participantes variavam entre empresários, ativistas, programadores e

\footnotetext{
35 “Art. 10. Não se considera invenção nem modelo de utilidade:

(...)

V - programas de computador em si;",

${ }^{36} \mathrm{O}$ titular desses direitos autorais não necessariamente será aquele quem criou ou desenvolveu o programa. De acordo com o artigo $4^{\circ}$ da legislação específica, poderão pertencer ao empregador ou contratante de serviço a titularidade do copyright dos softwares, desenvolvidos ou elaborados durante a vigência do contrato ou vínculo estatuário, destinados a pesquisa e desenvolvimento ou que decorram da atividade contratada. Ademais, o titular de tais direitos também poderá, por meio de instrumento particular ou público, ceder parcialmente ou totalmente em favor de terceiro os direitos patrimoniais, na linha do artigo 49 da Lei $n^{\circ} 9.610 / 1998$ e o caput do artigo $2^{\circ}$ da Lei $\mathrm{n}^{\circ}$ 9.609/1998.

${ }^{37}$ Os direitos autorais não garantem aos titulares o monopólio sob a funcionalidade do código-fonte apenas quanto a expressão, sendo esse o motivo de alguns empresários da informática desejarem o regime de patentes ou modelos de utilidades para a concessão do monopólio quanto a função.
} 
pensadores, que enxergavam a proteção dos segredos do código-fonte aliado ao uso do copyright algo desvantajoso para sociedade e para a tecnologia da informática.

Sob tais premissas, foi elaborado o Projeto GNU e sugeridas modalidades de licenças que preservem algumas liberdades essenciais sendo rotuladas como licenças copyleft, são essas liberdades sobre o código-fonte: a) de usar; b) estudar; c) copiar e compartilhar; além de d) modificar, criar derivações e compartilhá-las. Consequentemente a esses direitos cedidos aos licenciados, há a obrigação de manter o código-fonte, suas modificações e derivações sob as diretrizes do copyleft estipulado na licença ${ }^{38}$.

Nesse segmento, as supramencionadas formas de contratos podem possuir diferente níveis de liberdade e não necessariamente implicam a rejeição aos direitos autorais pelo titular, tampouco a renúncia a exploração econômica do programa. Em outras palavras, as modalidades não são uma negação total ao copyright, mas uma forma alternativa de exploração ao titular desses direitos na atividade empresarial e desenvolvimento tecnológico.

\section{O LICENCIAMENTO DOS PROGRAMAS DE COMPUTADOR}

O Direito tutela algumas situações fáticas prescritas em hipóteses legais contidas em normas jurídicas, resguardando que os efeitos prelecionados nos textos legais sejam soberanos. Em outras palavras, o ordenamento jurídico delega proteção, o direito subjetivo de provocar o Judiciário ou Juízo Arbitral ${ }^{39}$, aos fatos cotidianos significantes na vida civil.

As supramencionadas hipóteses, extraídas das normas vigentes no sistema de leis brasileiros, são denominados fatos jurídicos ${ }^{40}$ que podem ser classificados de acordo com a conduta do agente que resulte o acontecimento no mundo fenomenológico. Consequentemente, quando essas conjecturas ocorrem há a causa genética das relações jurídicas ou a modificação

\footnotetext{
38 PIMENTEL, Luiz Otávio; SILVA, Cláudio Eduardo Regis de Figueiredo e. Conceito jurídico de software, padrão proprietário e livre: políticas públicas. Sequência (Florianópolis), Florianópolis, n. 68, p. 291-329, jun. 2014, p. 314.

${ }^{39}$ Consoante o artigo $5^{\circ}, \mathrm{XXXV}$, da $\mathrm{CF} / 88$, garante como direito fundamental o direito subjetivo de levar às cortes brasileiras controvérsias. Nesse segmento, o artigo $1^{\circ}$ da Lei $n^{\circ} 9.307 / 1996$, permite aqueles que estejam em gozo da sua capacidade civil levar controvérsias quanto a direitos patrimoniais à juízos privados, cuja constitucionalidade foi afirmada no julgado SE 5.206 pelo Supremo Tribunal Federal.

${ }^{40}$ COELHO, Fábio Ulhoa. Curso de direito civil: parte geral, volume 1. 5. ed. - São Paulo: Saraiva, 2012 , p. 631. ISBN 978-85-02-17360-6. Disponível em: http://lelivros.bid/book/download-curso-de-direito-civil-vol-1-partegeral-fabio-ulhoa-coelho-em-epub-mobi-pdf/>. Acesso em: 20 ago. 2018
} 


\section{AS LICENÇAS DE COPYRIGHT E COPYLEFT NOS SOFTWARES \\ E-ISSN 2316-8080}

dessas, estabelecendo obrigações entre os envolvidos ${ }^{41}$ que garantem o referido direito de ação oponível a violações aos direitos.

Consoante essa narrativa, quando há a elaboração de uma expressão que empregue uma linguagem, ainda que criptografada, em um dispositivo eletrônico para fazê-lo funcionar de determinado modo por um agente brasileiro ou estrangeiro lhe é garantido o copyright sobre essa obra, sob fundamentos do artigo $1^{\circ}$ e $2^{\circ}$ da Lei dos Softwares, oponível à terceiros ${ }^{42}$. Esse ato jurídico em sentido estrito ${ }^{43}$ estabelece o dever erga omnes de não utilizar, sem a autorização, do titular do direito essa expressão, sob pena prevista no artigo 12, para matéria criminal, e 14, quanto ao mérito civil, da mencionada lei.

Em outras palavras, independe da vontade do criador do programa de computador a proteção delegada pelos direitos autorais, tampouco lhe é imposto o dever de publicar sua criação. Ademais, o regimento legal, teoricamente, transcende a barreira nacionais, em virtude do artigo $2^{\circ}, \S 4^{\circ}$, da Lei ${ }^{\circ}$ 9.609/1998, artigo $1^{\circ}$, (1), do TRIPs, o artigo 3, (1), da Convenção de Berna, todavia, há como obstáculo o custo legal para litigar em escala internacional.

Sob tais fundamentos, o autor tem acesso desde o momento da criação do programa ao mecanismo de controvérsias judicial e extrajudicial em face de usos não-autorizados de suas obras por terceiros. Todavia, tal proteção não é suficiente para a exploração comercial dos softwares e tampouco totalmente eficaz para preservação da propriedade intelectual, por essa razão é facultado ao autor o direito de negociar o aspecto patrimonial de sua obra ${ }^{44}$, com o fulcro nos artigos $9^{\circ}$ ao 11 da Lei do Softwares.

O titular do copyright, então, pode celebrar negócios jurídicos com terceiros designando a modulação de efeitos legais que atentem sua necessidade, desejo e modelo de negócio ${ }^{45}$. Os

\footnotetext{
${ }^{41}$ GAGLIANO, Pablo Stolze; PAMPLONA FILHO, Rodolfo. Novo curso de direito civil, volume 1: parte geral. 15. ed. rev., atual e ampl. - São Paulo: Saraiva, 2013, p. 340.

${ }^{42}$ Tais direitos são limitados pelo artigo $6^{\circ}$ da Lei dos Softwares e as disposições compatíveis previstas no Capítulo IV da Lei de Direitos Autorais, sendo essas cláusulas de check in balance ao direito à propriedade intelectual e forma de evitar abusos de direito por parte do autor ou titular do copyright.

${ }^{43} \mathrm{O}$ ato jurídico em sentido estrito é a espécie de fato jurídico no qual a conduta do agente coaduna com uma conjectura legal prescrita em alguma lei, sendo dispensado animus pelos efeitos legais prelecionados na norma jurídica vigente. GAGLIANO, Pablo Stolze; PAMPLONA FILHO, Rodolfo. Novo curso de direito civil, volume 1: parte geral. 15. ed. rev., atual e ampl. - São Paulo: Saraiva, 2013, p. 349

${ }^{44} \mathrm{O}$ uso da negociação para salvaguardar os direitos autorais trata-se do emprego do método autocompositivo, cujo o emprego pode ser feito de 3 (três) maneiras: "São três as formas de autocomposição (as quais sobrevivem até hoje com referência aos interesses disponíveis): a) desistência (renúncia à pretensão); b) submissão (renúncia à resistência oferecida à pretensão); c) transação (concessões recíprocas). Todas essas soluções têm em comum a circunstância de serem parciais - no sentido de que dependem da vontade e da atividade de uma ou de ambas as partes envolvidas". CINTRA, Antônio Carlos de Araújo; GRINOVER, Ada Pellegrini; DINAMARCO, Cândido Rangel. Teoria geral do processo. 29. ed. São Paulo: Malheiros, 2007, p. 29.

${ }^{45}$ GONÇALVEZ, Carlos Roberto. Direito civil brasileiro: parte geral. 19. ed. - São Paulo: Saraiva, 2012, p. 314. ISBN 978-85-02-17479-5. Disponível em: http://lelivros.bid/book/download-direito-civil-parte-geral-19a-ed2012-carlos-roberto-goncalves-em-epub-mobi-pdf/>. Acesso em: 11 ago. 18.
} 
negócios jurídicos, por sua vez, são espécies de fato jurídico no qual o dono daquele direito seleciona os efeitos da norma possíveis em consonância a sua vontade, sobre isso leciona Reale:

\begin{abstract}
Negócio é aquela espécie de ato jurídico que, além de se originar de um ato de vontade, implica a declaração expressa da vontade, instauradora de uma relação entre dois ou mais sujeitos tendo em vista um objetivo protegido pelo ordenamento jurídico. Tais atos, que culminam numa relação intersubjetiva, não se confundem com atos jurídicos em sentido estrito, nos quais não há acordo de vontade, como, por exemplo, sé da nos atos chamados matérias, como os da ocupação ou posse de um terreno, a edificação de uma casa no terreno, apossado, um contrato de compra e venda, ao contrário, tem sua forma especifica de um negócio jurídico ${ }^{46}$.
\end{abstract}

Nesse diapasão, há disponível ao proprietário do programa de computador 2 (duas) formas de realizar seus direitos autorais: por meios de contratos e/ou procedimentos litigiosos. A exploração comercial da obra por negócios pode ser objeto de controle do Poder Judiciário ou Juízo Arbitral, caso disponha convenção de arbitragem, sendo analisado o contrato sob os 3 (três) planos do negócio jurídico: a) existência; b) validade; e, c) eficácia.

Os mencionados aspectos são formas do exercício e assistência do controle heterocompositivo ${ }^{47}$ sob as relações privadas, tratam-se de mecanismo de check in balance para que a autonomia privada não seja violada e os animus do negociado seja eficaz.

\title{
3.1 Os atributos da existência, validade e eficácia e a autonomia privada nos contratos de software
}

A autonomia da vontade é o princípio que resguarda o exercício sobre os direitos de acordo com os interesses individual. Tal preceito, é essencialmente político, sendo o direito de autogovernar-se durante os atos da vida civil sem submeter-se a ordens externas ${ }^{48}$. Todavia, não é um principio absoluto, estando sujeito as mitigações legais ${ }^{49}$.

\footnotetext{
${ }^{46}$ REALE, Miguel. Lições Preliminares de direito. 27. ed. São Paulo: Saraiva, 2004, p. 208-209.

${ }^{47}$ São 3 (três) os tipos de soluções de conflitos permitidos por lei: a) a autotutela, b) a composição e c) heterocomposição. No primeiro, a parte usa dos próprios meios para solucionar a controvérsia, em seguida, há a opção da negociação de interesses relacionado ao que é controvertido, por fim, a decisão de um terceiro externo a controvérsia para solucionar. SÁ FILHO, Fábio Menezes de. Análise da Admissibilidade da Resolução de Conflitos Individuais Afetos ao Direito Laboral Desportivo pela Arbitragem no Brasil. In: Melo Filho, Álvaro; SÁ FILHO, Fábio Menezes de; SOUZA NETO, Fernando Tasso de; RAMOS, Rafael Texeira (Coord). Direito do Trabalho Desportivo - Homenagem ao Professor Albino Mendes Baptista. Recife: Quartier Latin, 2012.

${ }^{48}$ CABRAL, Érico de Pina. A "autonomia" no direito privado. Revista de Direito Privado, São Paulo, v. 19, n. 5, p. 83-129, jul./set. 2004, p. 90-91.

${ }^{49}$ DINIZ, Maria Helena. Curso de direito civil brasileiro: teoria das obrigações contratuais e extracontratuais. 27 ed. São Paulo: Saraiva, 2011, p. 40-41.
} 
Sob esse entendimento, a autonomia da vontade desdobrasse em outros princípios sendo o mais importante para esse trabalho a autonomia privada. Sobre ele comenta Fachin, in verbis:

\begin{abstract}
É significativo o fato de que a autonomia privada é tida como sendo pedra angular do sistema civilístico inserido em contexto econômico-político próprio. A análise da autonomia privada, cuja expressão é autonomia da vontade, está diretamente vinculada ao espaço que o universo jurídico reserva aos particulares para disporem sobre seus interesses. Em verdade, a autonomia privada tem um reconhecimento da ordem jurídica, na medida em que a própria lei confere explicitamente o espaço em branco para que os particulares o preencham. Esse reconhecimento decorre da aplicação de um critério de exclusão, pois os particulares atuam nos espaços permitidos, isto é, não vedados pela ordem jurídica ${ }^{50}$
\end{abstract}

Os negócios jurídicos são frutos da autonomia privada, como já exposto, sendo inerente o caráter negocial no sentido de modular os efeitos legais previstos por lei de acordo com o designo da parte ou partes. A prima facie tal fato jurídico deve primeiro esta previsto no ordenamento, isto é, a situação fática deve coadunar com o suporte-legal, sendo esse o aspecto da existência do negócio jurídico composto por: a) sujeito de direito; b) manifestação da vontade em produzir tais efeitos obrigacionais; c) objeto possível de existir e determinável; e, por fim, d) a forma pela qual é manifestado o animus dos envolvidos ${ }^{51}$.

Sob esse fundamento, uma negociação que verse sobre direitos autorais precisa ser feita entre ao menos 1 (um) sujeitos de direitos, devendo haver a manifestação do desejo pelas instaurações de obrigações relativas a obra, que deve ser delimitada e identificável, e, por fim, o processo volitivo deve está livre de constrangimentos físicos irresistível (vis absoluta), a ausência dessas característica qualifica o contrato como inexistente e nulo de pleno direito. Nesse exame, não há avaliação quanto a qualidade do fato jurídico, havendo apenas a constatação da sua correspondência com as hipóteses legais do ordenamento jurídico brasileiro.

Adiante, o negócio celebrado deve ter certas qualidades para ter seus efeitos legais admitidos pela ordem jurídica, passando pelo "filtro de impurezas" atribuído pelo plano da validade que exige certas propriedades no contrato $^{52}$, são elas: a) a capacidade civil do agente; b) objeto lícito, possível e determinado; c) forma prevista em lei; d) livre manifestação da vontade; e) boa-fé ${ }^{53}$. Id est, o negociante deve ter capacidade civil plena, ou está assistido, e ter

\footnotetext{
${ }^{50}$ FACHIN, Luiz Edson. Novo conceito de ato e negócio jurídico. Curitiba: Educa, Scientia et Labor, 1988, p. 54.

${ }^{51}$ AZEVEDO, Antônio Junqueira de. Negócio jurídico: existência, validade e eficácia. 4. ed. São Paulo: Saraiva, 2002, p. 32-33.

52 AZEVEDO, Antônio Junqueira de. Negócio jurídico: existência, validade e eficácia. 4. ed. São Paulo: Saraiva, 2002, p. 42.

${ }^{53}$ GAGLIANO, Pablo Stolze; PAMPLONA FILHO, Rodolfo. Novo curso de direito civil, volume 1: parte geral. 15. ed. rev., atual e ampl. - São Paulo: Saraiva, 2013, p.378.
} 
a titularidade do copyright, ou procuração que delegue poderes para negocia-lo, o objeto do direito negociado deve enquadrar nas hipóteses legais da Lei de Software - atentar as disposições do artigo $6^{\circ}$ da mencionada legislação e as disposições quanto as limitações aos direito autorais - além de determinado, o instrumento do acordo deve observar as exigências expressas da lei e a celebração deve ter sido livre de vícios sob a vontade e segundo um dever ético.

Os mencionados vícios quanto a livre manifestação de vontade são elementos externos ao processo volitivo que originou o negócio jurídico, podendo ser em decorrência da indução ao erro o uso, atual ou eminente, de força resistível, estado de perigo ou lesão e hipóteses de ser vítima de fraude e violações a boa-fé. Tais defeitos podem causar a nulidade ou podem ser anuláveis decretando efeitos ex tunc ou ex nunc ${ }^{54}$.

Ademais, o escrutino desse plano adjetivo deve ser feito durante a negociação pelos envolvidos, sob pena de revisão judicial ou extrajudicial que pode culminar na nulidade dos efeitos de determinadas cláusulas, aspectos, ou em todo o negócio jurídico. Nesse sentido, a invalidade do negócio jurídico não impede a prática dos efeitos legais sendo necessário acionar o Poder Judiciário ou o Juízo Arbitral para o exercício do controle sob as consequências legais e fáticas.

Por fim, há o plano da eficácia sob os negócios jurídicos que tratam quanto a modulação dos efeitos das obrigações estabelecidas no acordo. Nesse parâmetro o negócio jurídico é controlado quanto a produção dos efeitos sob os direitos autorais, se são cabíveis segundo as disposições no instrumento contratual, princípios e normas vigentes no ordenamento jurídico.

Os 3 (três) atributos explanados são verdadeiros limites lógicos e éticos colocados a autonomia privada, impedindo que a firmação de contratos injustamente onerosos, fraudes e violações as garantias e direitos individuais tuteladas pelo ordenamento jurídico nacional.

\subsection{A declaração de vontade e a interpretação dos contratos de direitos autorais}

Ante os limites da autonomia privada exposto, é fundamental apreciar a declaração da vontade e a interpretação dos contratos de programas de computadores, aspectos fundamentais que resguardam a segurança jurídica do proprietário e do licenciado. Nessa toada, cabe lembrar

\footnotetext{
${ }^{54}$ COELHO, Fábio Ulhoa. Curso de direito civil: parte geral, volume 1. 5. ed. - São Paulo: Saraiva, 2012, p. 738739. ISBN 978-85-02-17360-6. Disponível em: http://lelivros.bid/book/download-curso-de-direito-civil-vol-1parte-geral-fabio-ulhoa-coelho-em-epub-mobi-pdf/>. Acesso em: 20 ago. 2018
} 


\section{AS LICENÇAS DE COPYRIGHT E COPYLEFT NOS SOFTWARES \\ E-ISSN 2316-8080}

o debate de 2 (duas) correntes antagônicas que defendiam: a) prevalência do ato volitivo em face do instrumento do contrato e b) a soberania do disposto na declaração sobre a vontade.

O primeiro segmento doutrinário remoto ao pensamento francês, o espírito iluminista e o liberalismo clássico, principal fonte da Revolução Francesa, ocorrida Século XVII ${ }^{55}$, defendendo uma exarcebação na importância da autonomia da vontade e elencando os contratos em posição superior ${ }^{56}$. Sob tais premissas, o próprio Estado era fruto da autonomia da vontade e tinha como função a garantia que o elemento volitivo fosse preservado.

Em outras palavras, a vontade era caracterizada como elemento presente no negócio jurídico, em proporções metafisicas, sendo, portanto, dever do Estado-Juiz tutelar proteções ao desejo de fórum íntimo das partes durante a celebração do contrato. Obviamente a inacessibilidade ao conhecimento desse designo garantia insegurança jurídica, pois, de acordo com tais premissas, o contrato poderia ser revisado quanto a sua existência, validade e eficácia, a um ponto que um novo negócio jurídico fosse celebrado no meio heterocompositivo.

A antítese a teoria volitiva foi adotada no Código Civil Alemão sendo conhecida como teoria da declaração da vontade na qual sobrepunha na interpretação dos contratos o disposto no instrumento da manifestação da vontade. A opção constituía uma crítica a doutrina francesa, fornecendo uma maior segurança jurídica aos negócios ao limitar as intervenções e controles sobre os contratos e suas cláusulas.

Todavia, a aplicação de ambas teorias na prática forense fora amenizadas sendo no caso francês defendido como mecanismo de salvaguarda o elemento volitivo interpretado segundo a declaração da vontade e no cenário germânico o instrumento do acordo interpretado de acordo ao elemento de fórum íntimo 57 .

\footnotetext{
${ }^{55}$ AZEVEDO, Antônio Junqueira de. Negócio jurídico: existência, validade e eficácia. 4. ed. São Paulo: Saraiva, 2002, p. 75.

56 “Continuando na mesma ordem de idéias, a verdade é que a teoria da vontade se apóia na fé da palavra dada, que está ligada ao princípio da autonomia da vontade e que constitui uma regra de moral social. Georges Ripert, expondo o princípio da autonomia da vontade, dá sua fase filosófica e histórica, nos seguintes termos: "Para afirmar a onipotência da vontade humana, criadora de obrigações, o Código Civil emprega, no art. 1.134, a expressão mais enérgica que se pode encontrar: 'as convenções legalmente formadas fazem lei entre as partes'. Para quem se lembra do culto à lei durante o período revolucionário, a fórmula parece singularmente forte. Para se chegar a essa concepção da vontade soberana, criando, por sua exclusiva força, direitos e obrigações, foi preciso que, na obra lenta dos séculos, a filosofia espiritualizasse o direito, para libertar a vontade pura, das formas materiais pelas quais ela se manifesta, que a religião cristã impusesse aos homens a fé na palavra escrupulosamente guardada, que a doutrina do direito natural ensinasse a superioridade do contrato, fundamentando nele a própria sociedade, que a teoria do individualismo liberal afirmasse a concordância dos interesses privados, livremente debatidos, com o bem público. Então, pôde reinar a doutrina da autonomia da vontade que é simultaneamente o reconhecimento e o exagero da onipotência do contrato".AZEVEDO, Antônio Junqueira de. Negócio jurídico: existência, validade e eficácia. 4. ed. São Paulo: Saraiva, 2002, p. 81.

57 "Dados esses aspectos gerais das duas teorias, passamos a apresentar nossa visão sobre elas. Cremos que tanto uma quanto a outra apresenta um erro na sua formulação inicial: ambas admitem a existência de dois elementos no negócio jurídico: a vontade e a declaração, divergindo somente quanto à prevalência de um e de outro. Ora, não
} 
No Brasil, a vontade tem sua função, na prática, durante a apreciação do atributo da eficácia, às vezes, no atributo de validade e, mais raramente, existência (no caso da vis absoluta) sendo absorvida pela declaração da vontade ${ }^{58}$. Nesse diapasão, a interpretação dos negócios jurídicos no Brasil é feita segundo a analise da declaração da vontade, que não se limita ao instrumento contratual englobando as circunstancias negociais, em busca da intenção do agente, logo se parte do objetivo ao subjetivo, sob o fulcro dos artigos 112 e 113 do Código Civil de $2002(\mathrm{CC} / 2002)^{59}$.

Ante o exposto, a interpretação dos contratos que versem direitos autorais é estabelecida de formas mais restritivas, no diapasão do artigo $4^{\circ}$ e 31 da Lei $n^{\circ} 9.610 / 1998$, os direitos que não estejam expressamente nas disposições no instrumento contratual não estão incluídos nas obrigações estabelecida no negócio. Ademais, o contrato deve especificar as formas que o direito de uso da obra está sendo cedido ou licenciado.

As disposições supramencionadas são aplicadas nos contratos de softwares em virtude do silêncio da lei especifica e o caráter subsidiário da Lei dos Direitos Autorais.

\section{3 modalidades de contratos de softwares}

Os contratos de programas de computadores podem apresentar diferentes modalidades, não havendo números clausulo na Lei de Software. Nesse sentido, podem ser celebrados a licença de uso, de comercio, de serviço, contratos de transferência de tecnologia, de cessão de direitos autorais e de know-how e outros. O primeiro trata-se da permissão para o uso por tempo determinado pelo licenciante, a um número determinado de usuários, e não exclusivo, a modalidade seguinte versa quanto a distribuição comercial ou e produção do programa de computador, os contratos de serviço versam quanto a implantação do software a uma funcionalidade.

Por fim, os contratos de cessão, know-how e transferência de tecnologia, tratam respectivamente: a) da transferência parcial ou total da titularidade dos direitos patrimoniais do copyright, b) da cooperação, compartilhamento treinamento de conhecimentos e técnicas e, por fim, c) da transferência do código-fonte do programa de computador.

há dois elementos, mas apenas um, e este é a declaração de vontade.”. AZEVEDO, Antônio Junqueira de. Negócio jurídico: existência, validade e eficácia. 4. ed. São Paulo: Saraiva, 2002, p. 82.

${ }^{58}$ AZEVEDO, Antônio Junqueira de. Negócio jurídico: existência, validade e eficácia. 4. ed. São Paulo: Saraiva, 2002, p. 83-84.

${ }^{59}$ AZEVEDO, Antônio Junqueira de. Negócio jurídico: existência, validade e eficácia. 4. ed. São Paulo: Saraiva, 2002, p. 102-103.

PIDCC, Aracaju/Se, Ano VIII, Volume 13 no 02, p.175 a 202 Jul/2019 | www.pidcc.com.br 
A lei especifica exige, no entanto, alguns elementos do instrumento contratual no caso da licença de comércio e de transferência de tecnologia. Na primeira modalidade, o acordo, ante o previsto no artigo 10 da Lei $n^{\circ} 9.609 / 1988$, deve conter: a) quem ficará responsável pelo pagamento; b) quantidade e a forma pela qual o licenciante será remunerado; e, c) quando se tratar de programação de origem estrangeira, deverá dispor quanto a responsabilidade aos encargos tributários e fiscais. Ainda os contratos de licença de comércio não poderão dispor de limites quanto a produção, distribuição ou comercialização, tampouco eximir de responsabilidades por ações de terceiros decorrente de defeitos, vícios ou violações do direito do autor.

Em seguida, o acordo de transferência de tecnologia, para ter efeito legais para terceiros, deverá ser averbado no Instituto Nacional de Propriedade Industrial. Além de ser pormenorizado as instruções quanto ao código-fonte e este disponibilizado.

\section{AS LICENÇAS COPYRIGHT X COPYLEFT}

Conforme explanado em tópicos anteriores, o direito à propriedade intelectual é um meio de tornar favorável o mercado para aqueles que desejam empreender nas atividades culturais, cientificas e tecnológicas. Sob esse aspecto, há críticas quanto a forma que tal direito é empregado e, até mesmo, a sua existência e compatibilidade com outros direitos.

Os direitos autorais sobre os softwares sem dúvida garantem a oportunidade a 1 (um) programador ou ao titular do direito de ter seus esforços remunerados e um mercado mais favorável ao seu empreendimento. Em virtude de ter a exclusividade quanto a exploração econômica daquele programa de computador.

Todavia, ainda há debates quanto ao benefício social que esse instituto gera a sociedade, o qual não é o foco desse trabalho. Nessa toada, há o copyleft uma forma de gerenciar os direitos autorais sob uma estratégia que permite uma maior liberdade sobre os avanços tecnológicos.

O empreendedor, então, tem a sua disposição as modalidades do copyright e do copyleft para exercer a atividade empresarial, tendo em vista seus fins, o modelo de negócio que deseja utilizar.

\subsection{Uma análise econômica da atividade autoral sob uma perspectiva austríaca}

Uma análise econômica começa com a constatação de que alguns axiomas básicos existem, o primeiro é a escassez de recursos que consequentemente leva ao problema da PIDCC, Aracaju/Se, Ano VIII, Volume 13 no 02, p.175 a 202 Jul/2019 | www.pidcc.com.br 
distribuição, utilização e a titularidade das decisões. Além dessa premissa fática relativa ao mundo, também deve ser levado em conta um estudo dos agentes que tomam as decisões, a estrutura da ação humana e outras variáveis.

Sob tal perspectiva, o economista e filosofo Ludwig von Mises elabora sua Magnum opus na qual aprecia a relação entre a escassez e a estrutura da ação humana. Nesse sentido, o autor formula que a ação é uma conduta racional motivada ${ }^{60}$ para sair de um estado de insatisfação para um estado de maior satisfação, renunciando recursos em favor de outros ${ }^{61}$, o famoso trade off. Em outras palavras, o homem age segundo propósitos subjetivos na consecução de fins, fazendo o cálculo entre o custo de sua ação, as escolhas dos meios, seu estado de insatisfação e o hipotético estado final de maior felicidade ${ }^{62}$.

Consoante tais fundamentos, pressupõe-se, então, mais 2 (dois) elementos para fundamentar uma boa teoria do mercado e do preço, são elas: o a) tempo e b) conhecimento.

O primeiro está ligado a noção de mudança, é impossível estudar precisamente a ação humana sem apreciar que toda conduta humana pressupõe uma ordem temporal, o agente distingue o tempo antes, durante e depois da sua conduta ${ }^{63}$. Sendo o tempo escasso, ele é um dos fatos que influenciam a conduta humana e a valorização dos seus objetivos ${ }^{64}$, uma vez que a ação é sempre dirigida para o futuro.

Por fim, há o conhecimento que também é deduzido do conceito de ação humana previamente exposto, consequente o agir ser propositado a um resultado no futuro o agente humano opera em um grau de incerteza. Tal incógnita é fundamento lógico ao agir, afinal, se o conhecimento fosse perfeito o ser humano não agiria, mas sim atuaria como um autômato aos estímulos externos e sendo desprovido de vontade ${ }^{65}$. Nessa toada, o homem na consecução de seus objetivos age segundo a probabilidade de caso, tendo conhecimento sobre alguns fatores e ignorância a outros ${ }^{66}$.

\footnotetext{
${ }^{60}$ MISES, Ludwig Von. Ação humana: um tratado de economia. 3.1 ed. São Paulo: Instituto Ludwig von Mises Brasil, 2010, p. 35.

${ }^{61}$ MISES, Ludwig Von. Ação humana: um tratado de economia. 3.1 ed. São Paulo: Instituto Ludwig von Mises Brasil, 2010, p. 37-38.

${ }^{62}$ MISES, Ludwig Von. Ação humana: um tratado de economia. 3.1 ed. São Paulo: Instituto Ludwig von Mises Brasil, 2010, p. 125-131.

${ }^{63}$ MISES, Ludwig Von. Ação humana: um tratado de economia. 3.1 ed. São Paulo: Instituto Ludwig von Mises Brasil, 2010, p. 134.

${ }^{64}$ MISES, Ludwig Von. Ação humana: um tratado de economia. 3.1 ed. São Paulo: Instituto Ludwig von Mises Brasil, 2010, p. 135-136

${ }^{65}$ MISES, Ludwig Von. Ação humana: um tratado de economia. 3.1 ed. São Paulo: Instituto Ludwig von Mises Brasil, 2010, p. 139.

${ }^{66}$ MISES, Ludwig Von. Ação humana: um tratado de economia. 3.1 ed. São Paulo: Instituto Ludwig von Mises Brasil, 2010, p. 144.
} 
Os 3 (três) fatos explanados: ação, tempo e conhecimento; são os fundamentos principais da análise da economia segundo a perspectiva austríaca ${ }^{67}$, o emprego desses elementos essências explicam a lei da utilidade marginal que resguarda o seguinte preceito: quanto maior a escassez de um bem mais valioso ele é ${ }^{68}$ e justificam o subjetivismo, isto é a criatividade no uso da autonomia da vontade na análise dos processos de mercado e a função empresarial $^{69}$.

Sob esses fundamentos, quando um indivíduo decide elaborar uma expressão literária artística ou cientifica, ele emprega o uso de bens escassos (o tempo, seu conhecimento sobre a coisa e os materiais usados para registrar) com o fim de satisfazer um desejo interno, seja ganhar dinheiro ou realizar um sonho. Nesse sentido há um trade off para ser um autor, o indivíduo renuncia os recursos gastos em favor da sua obra na esperança de que receberá algum lucro.

Consequentemente, o valor monetário dessa obra dependerá de sua abundância no mercado, a facilidade do acesso a ela, a utilidade subjetiva aos demais agentes, seus possíveis consumidores e, por fim, a quantidade de outros empreendedores que a vendam.

\subsection{O processo de mercado, o estado empresarial e o copyright nos programas de computador}

Assumindo que o autor deseja exercer profissionalmente a carreira criativa ou deseja lucrar com o seu trabalho, é do objetivo dele que a expressão criada seja vendida a um valor maior do que o gasto. A prima facie tal bem será escasso, em virtude da inexistência de alguém capaz de ordenar aquele exato padrão de ideias.

Entretanto, em razão da natureza imaterial, uma vez acessado por alguém além do autor aquela obra decresce em seu valor marginal, por estar sujeita a copias em outros suportesfísicos. Nesse sentido, o autor concorrerá com outras pessoas na venda de sua obra lhe sendo tolhido o "monopólio" inicial sob aquela expressão.

O sistema de direitos autorais nesse caso funciona como um limitador de concorrência em favor do autor e que preserva no mercado incentivos econômicos para a criação de novas obras, sendo esse o argumento utilitário o qual comumente justifica o instituto da propriedade

\footnotetext{
${ }^{67}$ IORIO, Ubiratan Jorge. Ação, tempo e conhecimento: A Escola Austríaca de economia. São Paulo: Instituto Ludwig von Mises, 2011, p. 30.

${ }^{68}$ ROTHBARD, Murray N. Man, Economy, and State: a treatise on economic principles with Power and Market government and the economy. 2. ed. Auburn: Ludwig von Mises Institute, 2009, p. 27-28.

${ }^{69}$ IORIO, Ubiratan Jorge. Ação, tempo e conhecimento: A Escola Austríaca de economia. São Paulo: Instituto Ludwig von Mises, 2011, p. 20.
} 
intelectual $^{70}$. Uma vez publicada, a expressão perde seu caráter escasso, devido ao desconhecimento $^{71}$, nesse sentido a preservação se dá como forma de controlar o acesso ao conhecimento para manter a escassez do produto de forma artificial.

A atividade empresarial está umbilicalmente ligada ao processo de mercado ${ }^{72}$ que consiste na descoberta constantes, através de acertos e erros, do preço justo daquele bem, em direção ao equilíbrio ${ }^{73}$. A função empresarial trabalha com a distribuição dispersa de conhecimentos na sociedade e a noção temporal. Isto é, o empresário é aquele que se encontra no estado de alerta a possíveis má alocações de recursos e possui informações sobre ela ${ }^{74}$ atuando no período em anterior ao conhecimento comum de todos os players do mercado.

No caso dos softwares, o autor elabora, com seu conhecimento, uma expressão que provoca o desempenho de uma funcionalidade em um dispositivo eletrônico. Nesse cenário, o empreendedor tem o interesse em manter essa expressão em monopólio para salvaguardar a exclusividade daquela funcionalidade no mercado para o seu produto/serviço, supondo que seja o desejo auferir o maior lucro possível.

O direito ao copyright nessa hipótese tem como função tornar mais oneroso aos concorrentes do dono software a disputa sobre código-fonte e sua funcionalidade no mercado, podendo provocar a cessação da competitividade. Ademais, essa sistemática legal permite potencialmente uma expansão na longevidade do programa. Todavia, há custos para aplicar tais direitos em uma situação concreta, exempli gratia, advogados, custas processuais, a demora processual e etc., sendo aconselhável a exploração a propriedade intelectual através de licenças.

O uso da criptografia do código-fonte, segredo comercial sobre a funcionalidade, mais o arcabouço legal dos direitos autorais pode garantir ao titular do direito do software um

70 LANDES, Willian M.; POSNER, Richard A. The economic structure of intellectual property law. Cambridge: THE Belknap Press of Harvard University Press, 2004, p. 11-12.

71 "Fundamentally, in a system where the knowledge of the relevant facts is dispersed among many people, prices can act to coördinate separate actions of different people in the same way as subjective values help the individual to coordinate the parts of his plan". HAYEK, F. A. The use of knowledge in society. The American Economic Review, Pittsburgh, v. 35, n. 4, p 519-530. set. 1945, p. 526.

${ }^{72}$ KIRZNER, Israel M. Competição e atividade empresarial. São Paulo: Instituto Ludwig von Mises, 2012 , p. 22.

73 "No equilíbrio, não há lugar para o empresário. Quando as decisões de todos os participantes do mercado se encaixam perfeitamente, de tal modo que cada plano pressupõe corretamente os planos correspondentes dos outros participantes, não existindo nenhuma possibilidade de qualquer alteração nesses planos, que passariam então a ser simultaneamente preferidos pelos participantes relevantes, não resta nada que o empresário possa fazer. Ele será incapaz de descobrir possibilidades de comprar daqueles que subestimaram a avidez de compradores potenciais e de, depois, vender aos compradores ávidos que poderiam, por sua vez, ter subestimado a avidez dos vendedores. Logo, ele não pode contribuir para uma realocação de recursos ou produtos que venha a vencer as ineficiências e a falta de coordenação geradas pela ignorância do mercado, já que não existe essa ignorância e falta de coordenação na situação de equilíbrio". KIRZNER, Israel M. Competição e atividade empresarial. São Paulo: Instituto Ludwig von Mises, 2012, p. 33-34.

${ }^{74}$ KIRZNER, Israel M. Competição e atividade empresarial. São Paulo: Instituto Ludwig von Mises, 2012, p. 23. 
mercado mais ameno em relação a concorrentes durante um prazo de tempo maior do que normalmente seria possível.

\subsection{Os fundamentos econômicos, a competição e a atividade empresarial na licença de modalidade copyleft}

A contraponto do sistema de direitos à propriedade intelectual mais restritivo, os titulares do copyright podem optar por um modelo de negócio mais participativo, no qual há o incentivo a uma competição maior e dirigida sob princípios mais liberais.

O copyleft como antes explanado tem como ideal a acessibilidade do conhecimento como motriz do desenvolvimento tecnológico. A permissão dada aos licenciados para modificar e derivar o código-fonte permitem uma maior quantidade de competidores no mercado e uma disputa mais acirrada.

Consoante o exposto, a atividade empresarial opera sob a má distribuição de recurso no mercado e a competição entre empresários permitem o processo rumo ao preço justo e a distribuição perfeitas. Todavia, apesar do norte do processo de mercado ser o equilíbrio em razão da subjetividade dos agentes tal ponto jamais será alcançado e o processo de mercado sempre continuará ${ }^{75}$. Em virtude do conhecimento imperfeito dos agentes nas operações sempre há margem para melhorar.

Aplicando tal lógica ao ato criativo do software, há sempre um espaço para a sofisticação da expressão em busca de melhores desempenhos na funcionalidade que essa provoca no dispositivo eletrônico. Nesse sentido, o autor do programa de computador pode sempre atualizar a sua criação para que esta fique mais refinada.

Nesse diapasão, torna-se uma opção mais barata ao autor disponibilizar o código-fonte sob a licença copyleft permitindo aos licenciados que compitam entre si e o titular do direito autoral, desempenhando o papel de erro e acerto mencionado para os avanços na programação do programa de computador ${ }^{76}$. Tal modelo de abordagem, permite ao proprietário do copyright gastar menos e ter um software mais refinado.

\footnotetext{
75 "In a kaleidic society the equilibrating forces, operating slowly, especially where much of the capital equipment is durable and specific, are always overtaken by unexpected change before they have done their work.... What emerges from out reflections is an image of the market as a particular kind of process, a continuous process without beginning or end, propelled by the interaction between the forces of equilibrium and the forces of change". LACHMANN, Ludwig M. From Mises to Shackle: An Essay on Austrian Economics and the Kaleidic Society, Journal of Economic Literature, v. 14, n. 1, pp. 54-62, mar. 1976, p. 61.

${ }^{76}$ HAYEK, F. A. Competition as a Discovery Procedure. In: HAYEK, F. A. New Studies in Philosophy, Politics, Economics and the History of Ideas. London: Routledge \& Kegan Paul. p. 179-90, 1978.
} 
Ademais, essa modalidade de licenciamento além de permitir ao proprietário maiores avanços com menos encargos também o torna conhecido, em razão da obrigação dos créditos ao licenciante dispostos no copyleft, e impede que programas derivados ou modificados sejam objeto de direito autorais de terceiros ${ }^{77}$. Em outras palavras, o titular do software se protege juridicamente de concorrente que pratiquem engenharia reversa, tem acesso ao emprego das inovações em sua obra e, por fim, constrói uma reputação no mercado.

Sob essa análise, o abordado tipo de licenciamento tem como característica acelerar o processo de mercado na obra e torná-la mais acessiva aos seus consumidores, ao passo que também previne a criação de monopólios derivados por engenharia reversa. O proprietário dos direitos do autor, então, tem a oportunidade de disputar com outros concorrentes, que não poderão valer-se do copyright contra ele sobre obras derivadas, diminuindo o custo judicial, com a vantagem de ser reconhecido ou ter sua marca reconhecida.

Em vista que o conhecimento é disperso na sociedade, os consumidores tendem a consumir produtos/serviços de empresas, por exemplo quando essas são conhecidas em decorrência do passado, não oferecem o melhor que tem no mercado. No cenário ilustrado, a modalidade de licença copyleft permite a divulgação e consolidação da empresa no mercado.

Logo, as vantagens hipotéticas dessa modalidade de licença são: a) um menor custo legal, b) mais resultados na pesquisa de desenvolvimento do programa de computador (resolução de bugs, melhoramento no desempenho de funcionalidade e etc.) a um menor custo em razão da natureza colaborativa, c) maior exposição do software no mercado que estará vinculado a empresa construindo uma reputação, d) maior vida útil do programa de computador graças as contribuições difusas e e) a compatibilidade com um maior número de programas em razão do grande número de programas derivados. Nesse diapasão, esse tipo de contrato pode fazer com que o mecanismo de competição e atividade empresarial impulsionem o autor do software a uma posição de concentração de mercado.

\section{CONCLUSÃO}

\footnotetext{
77 "Pode-se dizer, portanto, que o copyleft em muito se assemelha ao domínio público, já que permite qualquer uso, alteração, cópia e distribuição da obra sem necessidade de autorização específica do autor, que já forneceu a todos os interessados por meio de uma licença. Entretanto, distingue-se do domínio público por não permitir que as obras derivadas sejam licenciadas de outra forma que não segundo o copyleft".CERDEIRA, P. C. Copyleft e software livre: uma opção pela Razão - Eficiência Tecnológica, Econômica e Social - II. Revista da ABPI, São Paulo, n. 71, jul./ago. 2004.
} 
Os direitos a propriedade intelectual durante a Era da Informática enfrentam duros desafios em virtude da facilidade na pirataria, a cópia de obras literárias torna-se mais fácil e de velocidade quase instantânea, ao passo que os mecanismos de proteção ao direito autoral enfrentam a dificuldade da extraterritorialidade do cyberspace e um mecanismo de monitoramento eficaz. Nesse sentido, a estrutura da rede mundial de computadores oferece obstáculos ao monopólio legal sobre as expressões e a existência de um cenário competitivo mais acirrado, no caso dos softwares.

A descrição exposta ilustra o cenário em que o titular dos direitos autorias sobre programas de computador podem optar por diferentes formas de mercado cada qual com vantagens e pertinente a um modelo de negócios específico: o copyright, o copyleft e segredo comercial. Cada qual com suas vantagens e desvantagem permitem ao empreendedor a consecuções diferentes de metas.

Nesse diapasão, a hipótese apreciada nesse trabalho foi a de que a opção do copyright garantia, por meio de custos legais, um monopólio sobre a expressão com o objetivo de manter exclusiva a exploração comercial das funcionalidades desempenhadas pelo software. Nessa toada, a criptografia usada no código-fonte permite a ocultação da expressão tutelada e combinada ao sistema de licenças permite a atividade monopolística sobre o mercado. A contraponto, o uso do copyleft opera com os mecanismos de mudança do processo de mercado, através da atividade empresarial e a competição, poupando custos legais, concorrência com produtos derivados de engenharia reversa, difusão da reputação do criador/empresa e um processo mais rápido de aperfeiçoamento da expressão.

Sob os fundamentos da análise econômica sob a perspectiva da Escola Austríaca de Economia, é conclusivo que a hipótese se prova confirmada em virtude da natureza de não escassez de uma obra um dos modelos de tornar lucrativo após o acesso a expressão e a potencialização da cópia, é a atribuição artificial através do regime do copyright desdobrandose nas vantagens previstas na primeira metade da conjectura. Em relação a outra parte, a competição e atividade empresarial permitem que novas funcionalidades e aprimoramento a expressão sejam descobertas de forma difusa, em decorrência do acesso do código-fonte, e a obrigação dos créditos garantem a consagração da reputação no mercado. 


\section{REFERÊNCIAS}

ANDRADE, Elvira et al. Propriedade Intelectual em Software: o que podemos apreender da experiência internacional? Revista Brasileira de Inovação, Rio de Janeiro, v. 6, n. 1, p. 3153, janeiro/junho 2007.

AZEVEDO, Antônio Junqueira de. Negócio jurídico: existência, validade e eficácia. 4. ed. São Paulo: Saraiva, 2002.

BARLOW, John Perry. A declaration of the independence of cyberspace. 1996. Disponível em:https://www.eff.org/cyberspace-independence. Acesso em: 09 jun. 2018.

BRASIL. Lei no 9.609, de 19 de fevereiro de 1998. Dispõe sobre a proteção da propriedade intelectual de programa de computador, sua comercialização no País, e dá outras providências. Disponível em: http://www.planalto.gov.br/ccivil_03/leis/19609.htm. Acesso em: 10 set 2018.

BRASIL. Lei no 9.610, de 19 de fevereiro de 1998. Altera, atualiza e consolida a legislação sobre direitos autorais e dá outras providências. Disponível em:

http://www.planalto.gov.br/ccivil_03/leis/19610.htm. Acesso em: 10 set 2018.

BRASIL. Decreto no 75.572, de 8 de abril de 1975. Promulga a Convenção de Paris para a Proteção da Propriedade industrial revisão de Estocolmo, 1967. Disponível em: http://www2.camara.leg.br/legin/fed/decret/1970-1979/decreto-75572-8-abril-1975-424105publicacaooriginal-1-pe.html. Acesso em: 10 set 2018.

BRASL. Decreto $\mathbf{n}^{0} \mathbf{1 . 3 5 5}$, de 30 de dezembro de 1994. Promulga a Ata Final que Incorpora os Resultados da Rodada Uruguai de Negociações Comerciais Multilaterais do GATT. Disponível em: http://www.planalto.gov.br/ccivil_03/decreto/antigos/d1355.htm. Acesso em 10 set 2018.

CABELLO, Andrea Felippe; PÓBOA, Luciano Martins Costa. Análise econômica da primeira Lei de Patentes brasileiras. Estud. Econ., São Paulo, v. 46, n. 4, p. 870-907, dec. 2016.

CABRAL, Érico de Pina. A “autonomia” no direito privado. Revista de Direito Privado, São Paulo, v. 19, n. 5, p. 83-129, jul./set. 2004.

CERDEIRA, P. C. Copyleft e software livre: uma opção pela Razão - Eficiência Tecnológica, Econômica e Social - II. Revista da ABPI, São Paulo, n. 71, jul./ago. 2004.

CINTRA, Antônio Carlos de Araújo; GRINOVER, Ada Pellegrini; DINAMARCO, Cândido Rangel. Teoria geral do processo. 29. ed. São Paulo: Malheiros, 2007.

COELHO, Fábio Ulhoa. Curso de direito civil: parte geral, volume 1. 5. ed. - São Paulo: Saraiva, 2012, p. 631. ISBN 978-85-02-17360-6. Disponível em: http://lelivros.bid/book/download-curso-de-direito-civil-vol-1-parte-geral-fabio-ulhoa-coelhoem-epub-mobi-pdf/. Acesso em: 20 ago. 2018

DINIZ, Maria Helena. Curso de direito civil brasileiro: teoria das obrigações contratuais e extracontratuais. 27 ed. São Paulo: Saraiva, 2011. 
FACHIN, Luiz Edson. Novo conceito de ato e negócio jurídico. Curitiba: Educa, Scientia et Labor, 1988.

GAGLIANO, Pablo Stolze; PAMPLONA FILHO, Rodolfo. Novo curso de direito civil, volume 1: parte geral. 15. ed. rev., atual e ampl. - São Paulo: Saraiva, 2013.

GONÇALVEZ, Carlos Roberto. Direito civil brasileiro: parte geral. 19. ed. - São Paulo: Saraiva, 2012. ISBN 978-85-02-17479-5. Disponível em: http://lelivros.bid/book/downloaddireito-civil-parte-geral-19a-ed-2012-carlos-roberto-goncalves-em-epub-mobi-pdf/. Acesso em: 11 ago. 18.

HAYEK, Friedrich August von. The Use of Knowledge in Society. The American Economic Review, Pittsburgh, v. 35, n. 4, p 519-530. set. 1945.

HAYEK, Friedrich August von. Competition as a Discovery Procedure. In: HAYEK, F. A. New Studies in Philosophy, Politics, Economics and the History of Ideas. London: Routledge \& Kegan Paul. p. 179-90, 1978.

HOPPE, Hans-Hermann. A theory of socialism and capitalism. Boston: Kluwer Academic Publishers, 1989.

IORIO, Ubiratan Jorge. Ação, tempo e conhecimento: A Escola Austríaca de economia. São Paulo: Instituto Ludwig von Mises, 2011

KINSELLA, Stephan Kinsella. Against Intellectual Property. Journal of Libertarian Studies, v. 15, n. 2, p. 1-55, spring 2001.

KIRZNER, Israel M. Competição e atividade empresarial. São Paulo: Instituto Ludwig von Mises, 2012.

KOSTYLO, Joanna. From gunpowder to print: the common origins of copyright and patent. In: DEAZLEY, Ronan; KRETSCHMER, Martin; BENTLY, Lionel. Privilege and Property: Essays on the history of copyright. Cambridge OpenBook Publishers: 2010.

LACHMANN, Ludwig M. From Mises to Shackle: An Essay on Austrian Economics and the Kaleidic Society, Journal of Economic Literature, v. 14, n. 1, pp. 54-62, mar. 1976.

LANDES, Willian M.; POSNER, Richard A. The economic structure of intellectual property law. Cambridge: THE Belknap Press of Harvard University Press, 2004.

LÉVY, Pierre. O ciberespaço como um passo metaevolutivo. Revista FAMECOS, Porto Alegre, v. 7, nº 13, p. 59-67, dez., 2000.

MAY, Timothy C. The Cyphernomicon. 1994. Disponível em: http://www.cypherpunks.to/faq/cyphernomicron/cyphernomicon.html Acesso em: 01 set. 2018.

MISES, Ludwig Von. Ação humana: um tratado de economia. 3.1 ed. São Paulo: Instituto Ludwig von Mises Brasil, 2010.

MUSSO, Pierre. Critque des réseaux. Paris: Presses Universitaires de France, 2003. 
PIMENTEL, Luiz Otávio; SILVA, Cláudio Eduardo Regis de Figueiredo e. Conceito jurídico de software, padrão proprietário e livre: políticas públicas. Sequência (Florianópolis), Florianópolis, n. 68, p. 291-329, jun. 2014.

PIMENTEL, Luiz Otávio. O acordo sobre os aspectos dos direitos de propriedade intelectual relacionados com o comércio. Seqüência: Estudos Jurídicos e Políticos, Florianópolis, p. 167-196, jan. 2002. ISSN 2177-7055. Disponível em:

https://periodicos.ufsc.br/index.php/sequencia/article/view/15338. Acesso em: 08 set. 2018.

PLANT, Arnold. The economic theory concerning patents for inventions. In: PLANT, Arnold. Selected economic essays and addresses. London: Routledge \& Kegan Paul, 1974 ,p.36.

REALE, Miguel. Lições Preliminares de direito. 27. ed. São Paulo: Saraiva, 2004.

ROTHBARD, Murray N. Man, Economy, and State: a treatise on economic principles with Power and Market government and the economy. 2. ed. Auburn: Ludwig von Mises Institute, 2009.

SÁ FILHO, Fábio Menezes de. Análise da Admissibilidade da Resolução de Conflitos Individuais Afetos ao Direito Laboral Desportivo pela Arbitragem no Brasil. In: Melo Filho, Álvaro; SÁ FILHO, Fábio Menezes de; SOUZA NETO, Fernando Tasso de; RAMOS, Rafael Texeira (Coord). Direito do Trabalho Desportivo - Homenagem ao Professor Albino Mendes Baptista. Recife: Quartier Latin, 2012.

SARLET, Ingo Wolfgang. Dignidade (da pessoa) humana e direitos fundamentais na Constituição Federal de 1988. 10. ed. rev. atual. e ampl. - Porto Alegre: Livraria do Advogado Editora, 2015.

SARLET, Ingo Wolfgang. Os direitos fundamentais sociais como "cláusulas pétreas". Caderno de Direito, Piracicaba, v. 3, n. 5, p.78-97, jul./dez. 2003.

World Intelectual Property Organization. Intellectual Property Handbook: Police, Law and Use. 2. ed. Geneva: WIPO Publication, 2004

ZANINI. Leonardo Estevam de Assis. O Estatuto da Rainha Ana: estudos em comemoração dos 300 anos da primeira lei de copyright. Revista do Tribunal Regional Federal da $\mathbf{1}^{\mathbf{a}}$ Região, Brasília, v. 22, n. 9, ou. 2010. 